\title{
ON THE COVER
}

\section{Trilliums by R. Walter Heinrichs}

The following is based on an interview with the artist on January 14, 2021.

Robert Walter Heinrichs painted the trilliums on the cover when he was a graduate student. Many years later, he is professor emeritus of psychology and senior scholar at York University, Toronto, Canada, and in his retirement is writing a second book on schizophrenia. Back in 1981, he was struck by a photograph taken by Mary Ferguson in Canada: A year of the Land published by the National Film Board to celebrate the country's centennial: It reminded him of the woods around his family's cottage in eastern Ontario. He appreciated working from a photograph instead of doing a plein air painting, given the clouds of black flies present at that time of year.

The wild white trilliums is the official flower of the Canadian province of Ontario and is protected in several jurisdictions, including Michigan and Minnesota. They spread very slowly and can be killed by picking the flower or leaves. These spring blooms are found throughout most of eastern North America and parts of Asia. They have medicinal qualities: The astringent tonic derived from the root may stimulate the uterus (hence the common name birthroot or birthwort) and has also been used to control bleeding. Heinrichs commented that he is glad he titled his painting Trilliums rather than Birthworts.

The sloping spring hillside in the painting is emphasized in the shadows of the trees typical of the Great Lakes mixed forest. The pale green appears each year as the earth renews itself through blossoms and leaves. Soft sunshine picks out the trilliums that have dotted this woodland with white over many years.

Growing up in the small city of Kingston, Ontario, Heinrichs remembers drawing at an early age. His parents emigrated to Canada from Germany and his physician mother had done anatomical drawings in medical school, showing artistic ability. Heinrichs said he did poorly in elementary school art classes because he violated the teacher's prescriptive boundaries. She had definite expectations of what something should look like and a low grade resulted when they were not met. In high school he took art classes by mail and upon graduation in 1969, urged his parents to let him attend the Ontario College of Art in Toronto. His relatively strict mother and father were fearful about what their teenager might get up to on his own in the big city, fears that were completely justified, he now admits. However, they found an elderly couple who offered room and board, and with this in place his request was granted. The arrangement lasted about a month until he moved in with an art school friend.
His early days in Toronto provided a freedom not experienced in Kingston as he joined in the change and rebellion of the late 1960s when traditional artistic assumptions were challenged. He remembers hearing the phrase "art is not about painting naked ladies" repeated many times. Moreover, art was to be liberated from the "art-object." In a "conceptual" drawing class, instruction focused on "thinking" and no actual drawing. All this was exciting except when his parents arrived for an Open House. He felt embarrassed having to explain how a sneaker suspended from the ceiling could possibly be considered art. This iconoclastic kind of creative statement was amusing but also completely incomprehensible to them.

During art school, he became interested in psychology through exposure to the art of psychotic patients in a class taught by the psychoanalytically trained art historian John M. MacGregor. This started a thread that led to volunteer experience with serious mental illness, graduate school, and a lifelong interest in schizophrenia and neuroscience.

After art school Heinrichs knew that he did not want to pursue art as a career but was intrigued by how aesthetic perception interacted with childhood memories and personality as well as with cerebral hemispheric specialization. An early article published in the Journal of Personality reflected these interests, "Individual differences as predictors of preference in visual art" (Heinrichs \& Cupchik, 1985).

Heinrichs decided to augment his research interests with clinical skills in neuropsychological assessment to make a living. When he joined the staff at a psychiatric hospital, his early interests flooded back because at least half of the patients were diagnosed with schizophrenia. This opportunity led eventually to an academic appointment as well. His capstone tome, In Search of Madness: Schizophrenia and Neuroscience (Heinrichs, 2001; Oxford University Press), reflects the cumulative knowledge of his dedication to individuals challenged by schizophrenia.

His interest in art unabated, Heinrichs continues to draw and paint with a love for representing the natural landscape as well as abstract images that evoke excitement, release, and tranquility. In a recent project, he painted a mural on his garden shed, inspired by West African Kenta cloth designs. The legacy of art school days includes an appreciation of diversity in artistic expression and the knowledge that "pushing the envelope" is often-but not always-the best goal in art, as in research and life in general.

Sandra M. Fowler Art Co-Editor 